\title{
A study on farmers' choice in integrating paddy and cattle farming as farm management practices
}

\author{
N. A. A. Widarni, T. A. Kusumastuti and A. R. S. Putra* \\ ${ }^{1}$ Department of Livestock Social Economics, Faculty of Animal Science, \\ Universitas Gadjah Mada, Jl. Fauna No. 3, Bulaksumur, Yogyakarta 55281 - Indonesia \\ *Corresponding E-mail: ahmadromadhoni@ugm.ac.id
}

Received May 13, 2020; Accepted August 24, 2020

\begin{abstract}
ABSTRAK
Penelitian ini dilakukan untuk mengetahui teknologi pilihan petani dalam melakukan praktek integrasi padi dan sapi, sekaligus mencari faktor-faktor yang mempengaruhi keputusan petani dalam adopsi integrasi tersebut. Data primer didapatkan melalui wawancara personal dari 198 responden yang terbagi ke dalam tiga kategori ('tidak ada integrasi', 'integrasi parsial' dan 'integrasi penuh') berdasarkan pada penggunaan kotoran ternak dan jerami padi di Kabupaten Magelang, Jawa Tengah, Indonesia. Data dianalisis menggunakan multinomial logistik dengan 'tidak ada integrasi' sebagai kontrol. Hasil penelitian menunjukkan bahwa $60.6 \%$ petani telah melakukan 'integrasi penuh', meskipun mayoritas petani tidak menerapkan teknologi fermentasi baik pada kotoran ternak maupun jerami padi. Keputusan petani dalam menerapkan praktik integrasi padi dan sapi dipengaruhi oleh status kepemilikan lahan, pendidikan formal, frekuensi jumlah pelatihan yang pernah diikuti dan pengalaman bertani.
\end{abstract}

Kata kunci : adopsi, sistem pertanian terintegrasi, multinomial logit

\begin{abstract}
The study was conducted to examine the farmers' choice on the technology of the paddy and cattle integration farming and determine factors that affected the integrated adoption. Primary data were collected through personal interview from 198 respondents divided into three categories ('no integration', 'partial integration', and 'full integration') based on the farmer's utilization of manure and crop residues at Magelang Regency, Central Java Province, Indonesia. Then, the data were analyzed by multinomial logit by using 'no integration' as a baseline. The results revealed that $60.6 \%$ of farmers had applied 'full integration', although most farmers rarely adopt both fermentation and composting technology. In conclusion, formal education, frequency of training, and farming experience were found significant in affecting the integration of paddy and cattle farming practice.

Keywords: adoption, integrated farming system, multinomial logit
\end{abstract}

\section{INTRODUCTION}

Recently, an integrated farming system is considered a sustainable approach to improve soil fertility caused by the intensive agriculture (Lemaire et al., 2014; Kumar et al., 2014). The integrated farming system is not only known as an eco-friendly farming but also an efficient system that enhances small-scale farmers' income (Zingore et al., 2009; Uddin et al., 2015). The system promoted some technologies to utilize crop residues and livestock manure as an input to 
each enterprise (Lemaire et al., 2014; Soni et al., 2014). The linkage between crop and livestock has proven to improve soil fertility, increase crop production, reduce cost, and increase farmers' income (Rusinamhodzi et al., 2015; Uddin et al., 2015; Widadie and Agustono, 2015; Putra et al., 2017).

The implementation of integrated farming in the long-term increased the level of soil organic carbon (SOC) in Zimbabwe (Rusinamhodzi et al., 2015). Meanwhile, another study revealed that the income of integrated farmers was higher than non-integrated farmers by $25,28 \%$ in Bangladesh. The income also passed the national average income, while the non-integrated farmers' income was still under average (Uddin et al., 2015). Therefore, this approach is largely applied especially in developing countries where agriculture is still the backbone of national income and primary occupation by rural people (Kumar et al., 2014; Thornton and Herrero, 2015; Amare and Simane, 2017). Moreover, most of rural farmers only cultivated less than 2 hectares, while livestock production, mainly is the large animal, is relatively small (Rapsomanikis, 2015). In addition, this approach is expected to mitigate GHG emissions, in which the agriculture sector is one of the contributors (Munandar et al., 2015; Thornton and Herrero, 2015).

Based on the benefit of the integrated farming system that has been implemented by other countries for many years, then the Indonesian government broadly extended the practice of integrated farming, particularly in paddy and cattle commodities. Paddy is considered a staple food and the most crop cultivated by rural farmers which accounted for $66 \%$ as the most significant contributor in the food crop sub-sector for supporting the national income, while cattle are assumed as a vital instrument of establishing self-sufficient in farming (Mariyono, 2014; Agus and Widi, 2018).

The study in Benin, Africa, showed that $55 \%$ of farmers adopted partial integration that could be defined as a practice in utilizing either manure as fertilizer or crop residues as feed. Meanwhile, full integration was less adopted, only about $9.2 \%$ of farmers to be interested in the full practice (Koura et al., 2016). Farmer's characteristics still become factors affecting the adoption of integrated farming practices (Koura et al., 2016; Agustine et al., 2019; Putra et al., 2019; Widarni et al., 2020). Many studies also presented that farmers rarely utilized both composting and fermenting technologies (Case et al., 2017; TurCardona et al., 2018). Most farmers still used unprocessed manure to their farmland, and fresh straw as livestock feed (Case et al., 2017; Santoso and Prasetyono, 2018). However, there were lack of studies on how farmer decide to utilize the farming waste management technology in the relation to estimate the paddy and cattle integrated farming. Therefore, this study aims to examine the farmers' choice in practicing the technology of paddy and cattle integration by estimating the adoption of farming waste management technologies. The utilization of manure as fertilizer and straw as feed is selected as technologies to estimate how farmers manage the integration of paddy and cattle farming practice.

\section{MATERIALS AND METHODS}

The study was conducted in Magelang Regency, Central Java Province, Indonesia, from February until September 2019. The location was selected with consideration of (1.) The Paddy and Cattle Integrated Farming System had been delivered to farmers in the location, (2.) Agriculture becomes the primary income of the farmer's household, who both cultivated paddy and raised cattle. Multistage random sampling was adopted to select respondents from 198 smallholder farmers in 7 (seven) districts that are:

- 20 respondents from Bandongan district

- 45 respondents from Candimulyo district

- 9 respondents from Kaliangkrik district

- 13 respondents from Ngluwar district

- 28 respondents from Salam district

- 58 respondents from Sawangan district

- 25 respondents from Windusari district

Data were collected through face to face interviews with respondents. The questionnaire is used as an instrument of data collection, which consisted of farmer's demography characteristics and the used of crop and livestock residues. The definition of all the variables in this study is shown in Table 1.

The types of integration were divided into three categories based on the utilizing of manure and straw as farming resources (Koura et al., 2016). The three categories of paddy and cattle integration were identified as: (a) 'No integration' which farmer used neither manure to fertilize his paddy field nor rice straw as cattle feed, (b) 'Partial integration' which farmer used either 
Table 1. Description of The Variables

\begin{tabular}{|c|c|c|}
\hline Variables Type and name & Description and Measurement & Type \\
\hline \multicolumn{3}{|l|}{ Independent variables } \\
\hline Age & Age of main farmer in the household in years & Continuous \\
\hline Formal education & Formal education of main farmer in years & Continuous \\
\hline Experience & Experience on agriculture of main farmer in years & Continuous \\
\hline Participation & $\begin{array}{l}\text { whether main farmer participated in group }(1=\text { Yes, } \\
0=\text { No) }\end{array}$ & Dummy \\
\hline Frequency of training & Number of training that main farmer participated & Continuous \\
\hline Cattle & Total number of cattle kept by farmer & Continuous \\
\hline Cattle statue & whether cattle were owned by farmer $(1=$ Yes, $0=$ No) & Dummy \\
\hline Plot size & Total land that managed by farmer in hectare & Continuous \\
\hline \multicolumn{3}{|l|}{ Dependent variable } \\
\hline Category of integrated & $\begin{array}{l}\text { The category of integrated that adopted by farmer } \\
\text { ( } 1=\text { No integration, } 2=\text { Partial integration, } 3=\text { Full } \\
\text { integration) }\end{array}$ & Categorical \\
\hline
\end{tabular}

manure as fertilizer or rice straw as feed and (c) 'Full integration' which farmer used both manure as fertilizer and rice straw as feed.

The estimation model employs the multinomial logistic regression, which enables to identify the factors influencing the adoption with more than two discrete dependent variables (Lin et al., 2014). The influence of independent variables on dependent variables (i.e., no integration, partial integration, and full integration) is represented on the probability scores determining by the multinomial logit model (Rathod et al., 2017). The probability of farmers' choice to integrate paddy and cattle farming from partial integration to full integration is shown in $\mathrm{P}_{\alpha}$, using no integration as a baseline. The following equation can be described the multinomial logit model based on Rathod et al. (2017):

$$
P_{\alpha}=\operatorname{Pr}\left[Y_{\alpha}=b\right]=\frac{\exp \left(\beta_{b} X_{b}\right)}{\sum \exp \left(\beta_{b} X_{b}\right)}
$$

where $\operatorname{Pr}\left(Y_{\alpha}=b\right)$ means the probability of farmers' choice of the three choices. $\alpha$ is the chosen option, either no integration, partial integration or full integration. $X$ is the predictor variable vector, $\beta$ is the estimated parameter vector, and $b$ symbolize an individual of farmers. The estimated coefficients of multinomial logit model present the effect sign of independent variables on dependent variables (Amare and Simane, 2017). The marginal effect is estimated by STATA version 14 to measure each independent variable's change effect on the probability of farmers' choice in the integrated paddy and cattle farming practices (Alexander et al., 2005; Miheretu and Yimer, 2017).

\section{RESULTS AND DISCUSSION}

\section{Characteristics of Farmers}

Most farmers $(60.6 \%)$ were regarded as farmers who used manure as fertilizer and paddy straw as cattle feed, as shown in Figure 1. This result showed that farmers in Magelang Regency commonly practiced full integration farming.

As shown in Table 2, the average of farmers' age in all categories was 54.16 years old considered as in the productive age. The average of farmers' formal education of full integration was the highest $(7.78$ years $)$ or passed the $7^{\text {th }}$ grade of junior high school, meanwhile 6.63 years or passed the $6^{\text {th }}$ grade for partial integration, and 5.86 or passed the $5^{\text {th }}$ grade for no integration. A study in Ethiopia showed that education had a 


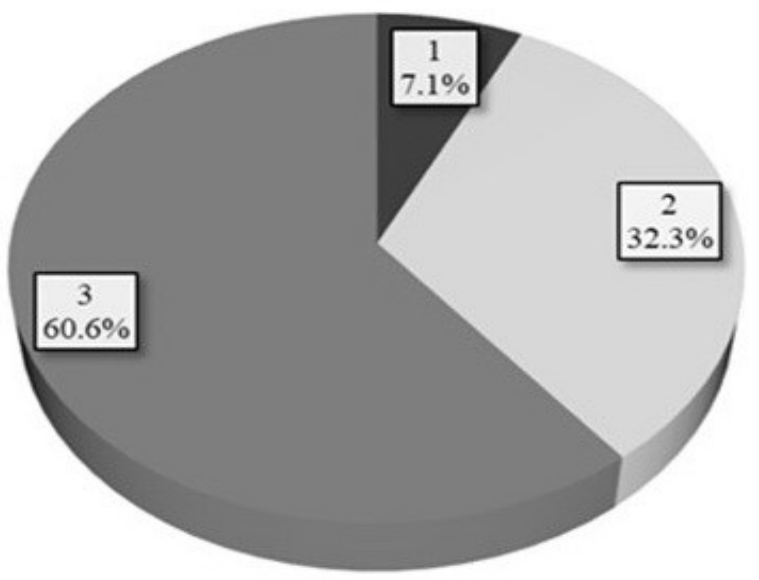

Figure 1. Farmers was Classified into Three Categories: (1) no integration, (2) partial integration, and (3) full integration.

Table 2. Descriptive Statistic of The Variables

\begin{tabular}{|c|c|c|c|c|c|}
\hline Variables & Unit & $\begin{array}{c}\text { Mean } \\
\text { (St. Dev) }\end{array}$ & $\begin{array}{l}\text { No Integration } \\
\text { Mean (St. Dev) }\end{array}$ & $\begin{array}{c}\text { Partial Integration } \\
\text { Mean (St. Dev) }\end{array}$ & $\begin{array}{l}\text { Full Integration } \\
\text { Mean (St. Dev) }\end{array}$ \\
\hline$\overline{\text { Age }}$ & Year & $\begin{array}{r}54.16 \\
(10.50)\end{array}$ & $\begin{array}{r}52.71 \\
(10.88)\end{array}$ & $\begin{array}{r}55.03 \\
(8.88)\end{array}$ & $\begin{array}{r}53.86 \\
(11.27)\end{array}$ \\
\hline Formal education & Year & $\begin{array}{r}7.27 \\
(3.38)\end{array}$ & $\begin{array}{r}5.86 \\
(2.93)\end{array}$ & $\begin{array}{r}6.63 \\
(3.39)\end{array}$ & $\begin{array}{r}7.78 \\
(3.35)\end{array}$ \\
\hline Experience & Year & $\begin{array}{r}26.91 \\
(14.65)\end{array}$ & $\begin{array}{r}20.84 \\
(13.17)\end{array}$ & $\begin{array}{r}28.55 \\
(12.86)\end{array}$ & $\begin{array}{r}26.75 \\
(15.58)\end{array}$ \\
\hline Participation & Dummy & $\begin{array}{r}0.75 \\
(0.43)\end{array}$ & $\begin{array}{r}0.79 \\
(0.43)\end{array}$ & $\begin{array}{r}0.72 \\
(0.45)\end{array}$ & $\begin{array}{r}0.77 \\
(0.42)\end{array}$ \\
\hline Frequency of training & Times & $\begin{array}{r}1.38 \\
(1.94)\end{array}$ & $\begin{array}{r}0.43 \\
(0.85)\end{array}$ & $\begin{array}{r}0.97 \\
(1.95)\end{array}$ & $\begin{array}{r}1.71 \\
(1.95)\end{array}$ \\
\hline Cattle & $\begin{array}{l}\text { Livestock } \\
\text { Unit }\end{array}$ & $\begin{array}{r}1.85 \\
(1.30)\end{array}$ & $\begin{array}{r}1.70 \\
(1.12)\end{array}$ & $\begin{array}{r}1.71 \\
(0.89)\end{array}$ & $\begin{array}{r}1.94 \\
(1.48)\end{array}$ \\
\hline Cattle statue & Dummy & $\begin{array}{r}0.64 \\
(0.48)\end{array}$ & $\begin{array}{r}0.50 \\
(0.52)\end{array}$ & $\begin{array}{r}0.64 \\
(0.48)\end{array}$ & $\begin{array}{r}0.66 \\
(0.48)\end{array}$ \\
\hline Plot size & Hectare & $\begin{array}{r}0.31 \\
(0.29)\end{array}$ & $\begin{array}{r}0.30 \\
(0.14)\end{array}$ & $\begin{array}{r}0.34 \\
(0.31)\end{array}$ & $\begin{array}{r}0.31 \\
(0.30)\end{array}$ \\
\hline
\end{tabular}

positive impact on sustainable agriculture practice. Education might help farmers to search and utilize some information that involved integrated farming practice (Amare and Simane, 2017).

Farmers who practiced no integration had the lowest average in experience, frequency of training, number of cattle in their herds, and the total area of paddy field. Most farmers of no integration category had never attended training in contrast to farmers in the other two categories. Farmers who are more experienced and trained are more likely to adopt new technology (Asare et al., 2013). The number of cattle that are kept by farmers of full integration was the highest (1.94), then partial integration (1.71), and the lowest was 
no integration (1.70).

\section{Farm Waste Management Technology}

Integration of paddy and cattle farming practices was disseminated in the selected districts of this study through many programs such as SIPT (Paddy and Livestock Integrated System) and SRI (System of Rice Intensification) for many years. In those programs, technologies of processing straw (fermenting) and manure (composting) were also disseminated.

The adopted technology of waste management, particularly both manure and crop residue processing by farmers, was presented in Table 3. It revealed that most farmers from both partial integration and full integration category used unprocessed manures as fertilizer $(64.7 \%)$ and fresh paddy straw as cattle feed $(76.6 \%)$. Some studies revealed that the main reason for farmers utilized manure as fertilizer was the ability of manure that could improve the soil fertility, while the main reason for farmers utilized straw as feed was farmers holding limited land fodder (Case et al., 2017; Baba et al., 2019). The present study showed that $59.1 \%$ of farmers cultivated elephant grass or king grass on the rice fields' edge, and $29.8 \%$ of farmers did not have land fodder. Only $11.1 \%$ of farmers have land fodder, but it is less than 0.5 ha.

Although most farmers practiced full integration farming, the technology of waste processing was less adopted. Only about $18.2 \%$ of farmers adopted the composting manure, and $3.6 \%$ of farmers adopted the fermented straw. The low rate of adoption on those technologies might due to the troublesome of technologies such as the more labor requirement, the need of more materials (such as the bacteria and other organic materials), and the high cost (Case et al., 2017; Baba et al., 2019). Aside from those troublesome, it could also be related to the complicated of those technologies and farmers hardly have leisure time (Lindawati et al., 2018; Baba et al., 2019). About $55.6 \%$ of farmers had other non-farming jobs, so they rarely had sufficient time, thereby reducing the intensity of the waste technology adoption.

\section{The Paddy and Cattle Integration Adoption}

The factors affecting the integration categories' adoption were examined by the multinomial logit model presenting in Table 4 . The estimated marginal effects and their significance levels were shown in Table 5. Among those variables, experience $(\mathrm{P}<0.05)$ and frequency of training $(\mathrm{P}<0.10)$ positively influenced the probability of partial integration practice. In the case of full integration, frequency of training $(\mathrm{P}<0.05)$, experience $(\mathrm{P}<0.05)$ and formal education $(\mathrm{P}<0.10)$ were significant while all the signs of the regression coefficient of those variables were positive.

Farming experience positively affected to the adoption of paddy and cattle farming practices for both partial and full integration, implying that the probability of adopting paddy and cattle integration increases along with farmers' longer farming experience. The estimation of marginal effect for farming experience indicated that a year increase in farming experience would decrease, at least, the intensity to adopt no integration practice by $0.03 \%$. Prior experiences have given farmers the thought about the inefficiency of nonintegrated farming so that they would realize the utilization of integrated farming. Those prior experiences also make farmers adopt integrated farming handily. A Caribbean Island study

Table 3. Technology Adopted by Farmer

\begin{tabular}{lccccc}
\hline \multirow{2}{*}{ Category } & \multicolumn{2}{c}{ Manure processing } & & \multicolumn{2}{c}{ Crops processing } \\
\cline { 2 - 3 } \cline { 5 - 6 } & No composting & Composting & & Fresh & Fermenting \\
\hline Partial integration & 17 & 0 & & 46 & 1 \\
& $(100 \%)$ & $(0.0 \%)$ & & $(97.9 \%)$ & $(2.1 \%)$ \\
Full integration & 95 & 25 & & 115 & 5 \\
& $(79.2 \%)$ & $(20.8 \%)$ & & $(95.8 \%)$ & $(4.2 \%)$ \\
Total & 114 & 25 & & 161 & 6 \\
& $(81.8 \%)$ & $(18.2 \%)$ & & $(96.4 \%)$ & $(3.6 \%)$ \\
\hline
\end{tabular}


Table 4. Determinants Affected the Adoption of Integration Category

\begin{tabular}{|c|c|c|c|c|c|}
\hline \multirow{2}{*}{\multicolumn{2}{|c|}{ Variables }} & \multicolumn{4}{|c|}{ Partial Integration } \\
\hline & & $\beta$ & St. Error & $\mathrm{z}$ & $\mathrm{p}$ value \\
\hline a. & No integration (as a baseline) & No outcome & & & \\
\hline \multicolumn{6}{|c|}{ b. Partial integration } \\
\hline & Age & 0.00426 & 0.03649 & 0.12 & 0.907 \\
\hline & Formal education & 0.12835 & 0.11273 & 1.14 & 0.255 \\
\hline & Experience & 0.05464 & 0.02754 & 1.98 & $0.047 * *$ \\
\hline & Participation & -1.12635 & 0.78578 & -1.43 & 0.152 \\
\hline & Frequency of training & 0.70953 & 0.42557 & 1.67 & $0.095 *$ \\
\hline & Cattle & -0.16836 & 0.33922 & -0.50 & 0.620 \\
\hline & Cattle statue & 0.20394 & 0.63841 & 0.32 & 0.749 \\
\hline & Plot size & -0.12336 & 1.30249 & -0.09 & 0.925 \\
\hline & Constanta & -0.25000 & 2.25625 & -0.11 & 0.912 \\
\hline \multicolumn{6}{|c|}{ c. Full integration } \\
\hline & Age & 0.01303 & 0.03544 & 0.37 & 0.713 \\
\hline & Formal education & 0.21607 & 0.11090 & 1.95 & $0.051^{*}$ \\
\hline & Experience & 0.05315 & 0.02685 & 1.98 & $0.048^{* *}$ \\
\hline & Participation & -1.19297 & 0.76964 & -1.55 & 0.121 \\
\hline & Frequency of training & 0.91497 & 0.42157 & 2.17 & 0.030 ** \\
\hline & Cattle & -0.01643 & 0.32561 & -0.05 & 0.960 \\
\hline & Cattle statue & 0.16935 & 0.62163 & 0.27 & 0.785 \\
\hline & Plot size & -0.87731 & 1.29942 & -0.68 & 0.500 \\
\hline & Constanta & -0.91244 & 2.21277 & -0.41 & 0.680 \\
\hline
\end{tabular}

Number of observations $=198$. LR chi2 $(18)=31.85 ;$ Prob $>$ chi2 $=* *$; Pseudo R2 $=0.0800 ; *$ Significant at level $10 \%$, ** Significant at level $5 \%, * * *$ Significant at level $1 \%$.

showed that farmers' experience would influence their attitudes about adopting integrated farming due to their ability and experience when applying a new practice (Paul et al., 2017).

The frequency of training had a positive influence on integrated farming practice for both partial and full integration. Meanwhile, formal education only affected the adoption of full integration. A unit increase in the training frequency would increase the probability of adopting full integration by $6.97 \%$ and decrease the probability of adopting no integration practice by $4.94 \%$ at once. A unit increase in the number of years of formal education would increase the intensity of adopting full integration by $2.37 \%$.
Education might increase farmers' literacy rates so they would explore more about integrated farming practice. Moreover, farmers who have a higher level of education will be more aware of the importance of attending the training. Farmers who participate in the training more frequently would get more required information and skills to implement integrated farming. The previous study showed that a higher level of education and training might enhance farmers' awareness and readiness to adopt the integration farming practice (Asare et al., 2013; Raghav and Sen, 2014; Paul et al., 2017). Those variables worked together in increasing farmers' understanding of the integration of paddy and cattle farming practices. 
Table 5. Marginal Effects from the Multinomial Logit of Paddy and Cattle Integrated Farming Practice

\begin{tabular}{|c|c|c|c|c|c|c|}
\hline \multirow{2}{*}{ Variables } & \multicolumn{2}{|c|}{ No Integration } & \multicolumn{2}{|c|}{ Partial Integration } & \multicolumn{2}{|c|}{ Full integration } \\
\hline & $\mathrm{dy} / \mathrm{dx}$ & $\mathrm{p}$ value & $\mathrm{dy} / \mathrm{dx}$ & $\mathrm{p}$ value & $\mathrm{dy} / \mathrm{dx}$ & $\mathrm{p}$ value \\
\hline Age & -0.00056 & 0.785 & -0.00151 & 0.725 & 0.00207 & 0.637 \\
\hline Formal education & -0.01070 & 0.102 & -0.01301 & 0.239 & 0.02371 & $0.034 * *$ \\
\hline Experience & -0.00320 & $0.043 * *$ & 0.00163 & 0.582 & 0.00157 & 0.605 \\
\hline Participation & 0.06944 & 0.126 & -0.01567 & 0.845 & -0.05377 & 0.514 \\
\hline Frequency of training & -0.04942 & $0.055^{*}$ & -0.02031 & 0.422 & 0.06973 & $0.008 * * *$ \\
\hline Cattle & 0.00475 & 0.802 & -0.03223 & 0.376 & 0.02748 & 0.454 \\
\hline Cattle statue & -0.01095 & 0.761 & 0.01145 & 0.871 & -0.00050 & 0.994 \\
\hline Plot size & 0.03356 & 0.657 & 0.13615 & 0.222 & -0.16971 & 0.148 \\
\hline
\end{tabular}

*Significant at level 10\%, ** Significant at level 5\%,***Significant at level $1 \%$.

\section{CONCLUSION}

Most farmers who cultivated paddy and kept cattle in Magelang Regency were categorized as full integration farmers. The determinant factors that significantly affected the integration of paddy and cattle farming practices were farming experience, frequency of training, and formal education. Farmers who had more experience would decrease the intention to have no integration farming practice, while formal education would increase the probability of adopting full integration. Farmers who often participated in the training about integrated farming would also increase the probability of practicing full integration. However, the processing technology for both cattle manure and paddy straw were less adopted by farmers. This might indicate that the paddy and cattle integration practiced by farmers remained in a traditional practice approach rather than a technological approach.

\section{ACKNOWLEDGMENTS}

The authors would like to thank Education and Ministry of Research, Technology, and Higher Education of the Republic of Indonesia for the funding support of the research (Contract No. 2565/UN1.DITLIT/DITLIT/LT/2019), and also Universitas Gadjah Mada through "Rekognisi Tugas Akhir Scheme in 2019" (Contract No. 2129/UN1/DITLIT/DIT-LIT/LT/2019). We are grateful to Agriculture and Food Service also Livestock and Fishery Service in Magelang
Regency. Our gratitude is also extended to all extension agents and farmers groups, especially in Bandongan, Candimulyo, Kaliangkrik, Ngluwar, Salam, Sawangan, and Windusari District.

\section{REFERENCES}

Agus, A. and T. S. M. Widi. 2018. Current situation and future prospects for beef cattle production in Indonesia - A Review. AsianAustral J. Anim.Sci. 31(7):1-8.

Agustine, R., S. Bintara, S. Andarwati, M. A. U. Muzayyanah, T. S. M. Widi and A. R. S. Putra. 2019. Analysis in making decision of farmer to select bull frozen semen in Indonesia. J. Indonesian Trop. Anim. Agric. 44(3):323-332.

Alexander, C. E., C. A. Wilson and D. H. Foley. 2005. Agricultural input market segments: Who is buying what? J. Agribus. 23(2):113132.

Amare, A. and B. Simane. 2017. Determinants of smallholder farmers' decision to adopt adaptation options to climate change and variability in the Muger Sub Basin of the Upper Blue Nile Basin of Ethiopia. Agric. Food Secur. 6(64):1-20.

Asare, R. B., J. A. Danquah and F. A. Frempong. 2013. Socioeconomic factors influencing adoption of codapec and cocoa high-tech technologies among small holder farmers in Central Region of Ghana. Am. J. Exp. Agric. 3(2):277-292.

Baba, S., M. I. A. Dagong and S. Sohrah. 2019. 
Factors affecting the adoption of agricultural by-products as feed by beef cattle farmers in Maros Regency of South Sulawesi, Indonesia. Trop. Anim. Sci. J. 42(1):76-80.

Case, S. D. C., M. Oelofse, Y. Hou, O. Oenema, and L.S. Jensen. 2017. Farmer perceptions and use of organic waste products as fertilisers - A survey study of potential benefits and barriers. Agric. Syst. 151:84-95.

Koura, B. I., H. Dedehouanou, H. L. Dossa, B. V. Kpanou, F. Houngdonougbo, P. Houngnandan, G. A. Mensah and M. Houinato. 2016. Determinants of croplivestock integration by small farmers in Benin. Int. J. Bio. Chem. Sci. 9(5):22722283.

Kumar, S., M. Q. Ansari, R. K. Naresh and V. Kumar. 2014. Integrating crop and livestock management for enhanced productivity, profitability and sustainability of the ricewheat system in North West India. Int. J. Life Sci. Biotechnol. Pharma Res. 3(2):7484.

Lemaire, G., A. Franzluebbers, P. C. de F. Carvalho and D. Dedieu. 2014. Integrated crop-livestock systems: Strategies to achieve synergy between agricultural production and environmental quality. Agric. Ecosyst. Environ. 190:4-8.

Lin, Y., X. Deng, X. Li and E. Ma. 2014. Comparison of multinomial logistic regression and logistic regression: Which is more efficient in allocating land use? Front. Earth Sci. 8(4):512-523.

Lindawati, L., N. Kusnadi, S. U. Kuntjoro and D. K. S. Swastika. 2018. The impact of input and output prices on the household economic behavior of rice-livestock integrated farming system (Rlifs) and non Rlifs farmers. Proceedings. International Conference on Agriculture, Environment, and Food Security (AEFS) 2017, Universitas Sumatera Utara, Medan, Indonesia, 7-8 November 2017. In IOP Conf. Ser.: Earth Environ. Sci. 122:p.012020.

Mariyono, J. 2014. Rice production in Indonesia: Policy and performance. Asia Pacific J. Public Administration. 36(2):123-134.

Miheretu, B. A. and A. A. Yimer. 2017. Determinants of farmers' adoption of land management practices in Gelana SubWatershed of Northern Highlands of Ethiopia. Ecol. Proces. 6(19):1-11.

Munandar, F. Gustiar, Yakup, R. Hayati and A. I.
Munawar. 2015. Crop-cattle integrated farming system: An alternative of climatic change mitigation. Media Peternakan. 38(2):95-103.

Paul, J., J. Sierra, F. Causeret, L. Guinde and J. Blazy. 2017. Factors affecting the adoption of compost use by farmers in small tropical Caribbean Islands. J. Clean. Prod. 142:13871396.

Putra, A. R. S., N. A. A. Widarni, W. Bawono, R. Agustine and T. A. Kusumastuti. 2019. Determinant factors of applying mixed crops and livestock farming in Indonesia. Proceeding. The $8^{\text {th }}$ International Seminar on Tropical Animal Production (ISTAP), Universitas Gadjah Mada, Yogyakarta, Indonesia, 23-25 September 2019. In IOP Conf. Ser.: Earth Environ. Sci. 387:p.012115.

Putra, A. R. S., Z. Liu, and M. Lund. 2017. The impact of biogas technology adoption for farm households - Empirical evidence from mixed crop and livestock farming systems in Indonesia. Renew. Sustain. Energy Rev. 74:1371-1378.

Raghav, S. and C. Sen. 2014. Socio-economic status of farmers and their perception about technology adoption: A case study. EPRA Int. J. Econ. Bus. Rev. 2(3):7-13.

Rapsomanikis, G. 2015. The Economic Lives of Smallholder Farmers: An Analysis Based on Houshold Data from Nine Countries. FAO. Rome.

Rathod, , P., M. Chander and G. C. Sharma. 2017. Adoption status of artificial insemination in Indian dairy sector: Application of multinomial logit model. J. Appl. Anim. Res. 45(1):442-446.

Rusinamhodzi, L., M. T. van Wijk, M. Corbeels, M. C. Rufino and K. E. Giller. 2015. Maize crop residue uses and trade-offs on smallholder crop-livestock farms in Zimbabwe: Economic implications of intensification. Agric. Ecosyst. Environ. 214:31-45.

Santoso, B. and B. W. H. E. Prasetyono. 2018. Planning of beef cattle development in District Blora, Central Java, Indonesia. Proceedings. The $2^{\text {nd }}$ International Conference on Energy, Environmental and Information System (ICENIS), Semarang, Indonesia, 15-16 Agustus 2017. In E3S Web Conf. 31:p.09022. 
Soni, , R. P., M. Katoch and R. Ladohia. 2014. Integrated farming systems - A review. J. Agric. Vet. Sci. 7(10):36-42.

Thornton, Philip K., and Mario Herrero. 2015. "Adapting to Climate Change in the Mixed Crop and Livestock Farming Systems in Sub-Saharan Africa." Nature Climate Change 5(9): 830-36.

Tur-Cardona, J., O. Bonnichsen, S. Speelman, A. Verspecht, L. Carpentier, L. Debruyne, F. Marchand, B. H. Jacobsen and J. Buysse. 2018. Farmers' reasons to accept bio-based fertilizers: A choice experiment in seven different European Countries. J. Clean. Prod. 197:406-416.

Uddin, M. T., M. A. Khan and M. M. Islam. 2015. Integrated farming and it's impact on farmers' livelihood in Bangladesh. SAARC J. Agric. 13(2):61-79.

Widadie, F. and Agustono. 2015. Comparison of integrated crop-livestock and non-integrated farming systems for financial feasibility, technical efficiency and adoption (Case of farmers in Gunung Kidul Regency, Yogyakarta, Indonesia). J. Int. Soc. Southeast Asian Agric. Sci. 21(1):31-45.

Widarni, N. A. A., A. Astuti, S. Andarwati, T. A. Kusumastuti and A. R. S. Putra. 2020. Determinants of the mixed crop and livestock farming practice among smallholder farmers in Magelang Regency, Central Java Province. Proceedings. International Conference on Agriculture, Environment, and Food Security (AEFS) 2019, Universitas Sumatera Utara, Medan, Indonesia, 10 October 2019. In IOP Conf. Ser.: Earth Environ. Sci. 454:p.012010.

Zingore, S., E. Gonzales-Estrada, R. J. Delve, M. Herrero, J. P. Dimes and K. E. Giller. 2009. An integrated evaluation of strategies for enhancing productivity and profitability of resource-constrained smallholder farms in Zimbabwe. Agric. Syst. 101(1-2):57-68. 